Pech, M., Prazakova, J., \& Pechova, L. (2020). The Evaluation of the Success Rate of Corporate Failure Prediction in a Five-Year Period. Journal of Competitiveness, 12(1), 108-124. https://doi.org/10.7441/ joc. 2020.01 .07

\title{
THE EVALUATION OF THE SUCCESS RATE OF CORPORATE FAILURE PREDICTION IN A FIVE-YEAR PERIOD
}

\section{- Martin Pech, Jaroslava Prazakova, Lucie Pechova}

\begin{abstract}
The development of bankruptcies in the Czech Republic is closely related to the impact of the global financial economic crisis, which, among other things, has also affected the competitiveness of Czech companies to a great extent. The future state of overall company financial health can be determined through prediction models. This paper discusses the history of financial analysis and the most widely used models, with the main purpose of the paper to compare the accuracy of various prediction models and to decide which model has the highest prediction success rate. The sample consisted of the total of 90 Czech companies, out of which $1 / 2$ were companies in bankruptcy and $1 / 2$ were non-bankrupt companies. Ratio indicators of given models were calculated from balance sheets as well as profit and loss statements for a five-year period. The reliability of the accurate classification of accounting units is verified by a confusion matrix. The highest total success rate of classification was achieved by Zmijevski model, which had the highest predictive value. Another partial objective of the paper is to determine whether the accuracy rate of the bankruptcy models changes with branches within which the companies operate. The hypothesis about differences between the branches is confirmed. The most statistically significant differences were shown between Wholesale and Retail and the Processing Industry, with the results of models varying among different branches. The results show that taking into account the branches the company is operating in is advisable for selecting prediction models.
\end{abstract}

Keywords: bankruptcy models, bankruptcy prediction, financial statement analysis, corporate finance, competitiveness

JEL Classification: G30, G33, M21

Received: June, 2019

1st Revision: January, 2020

Accepted: February, 2020

\section{INTRODUCTION}

Company failure and bankruptcy prediction have always been widely studied topics in business and scholarly research, and they continue to interest researchers today, with bankruptcy prediction a field of growing interest especially since the 2008 global financial crisis (Shi \& Li, 2019). A number of different methods for bankruptcy prediction or for revealing the tendency towards 
bankruptcy have been developed over the years. Certainly, the most commonly used methods for predictions are so-called bankruptcy models, which feature various methods although the goal remains the same - to distinguish bankrupt firms from financially healthy companies.

The challenge of current methods lies in the growing relevance of reporting the true financial state of the company. Determining the most appropriate method for predicting bankruptcy remains important for managers, owners and creditors alike. This has become an issue of great importance recently as many "creative accounting" practices and financial scandals have come to light (Remenaric et al., 2018). One way around this problem is to use multiple prediction methods as well as to describe the conditions under which these methods are best suited. The prediction success originally reported by authors has rarely been achieved in other researches, and this article aims to contribute to the examination of this important topic.

\section{THEORETICAL BACKGROUND}

Our theoretical background describes the history of previous and current methods of financial analysis and bankruptcy prediction in order to more fully understand these methods and to emphasize their importance for current companies.

For a company to be managed appropriately in financial terms, generally its financial situation along with its financial management must be observed. Financial analysis is an effective tool in the evaluation of a company's financial efficiency on the basis of data from financial reports, wherein the individual data are sorted, aggregated and measured reciprocally. Any financial decision-making must be supported with a financial analysis, the result of which forms the basis for management strategies of the company's structure, investment and pricing policy, stock management, etc. The main goal of this analysis is to provide information on the company's financial situation, which as generally described by researchers consists of the assessment of the past, the present and the contemplated future of the company's financial management. Nevertheless, the company's financial situation cannot be ascertained merely by the calculation of a financial statement analysis using only ratio and other performance indicators.

In the literature there has been a great deal of research surrounding the concepts of financial prediction with reference to bankruptcy and credibility models. Credibility and bankruptcy models are generated with the goal of the quick orientation of investors and creditors with the view of evaluating the given company according to its quality, i.e. its trustworthiness and performance. The objective of credibility models is to provide an evaluation according to the level of the financial health, i.e. whether the quality of the company under evaluation is good or poor. In this respect, these models reveal the level of company's quality based on its performance, a factor which is important for the decision-making processes of investors and owners, who cannot calculate a company's net current value without assistance due to the absence of necessary data (Neumaierová \& Neumaier, 2002). On the contrary, bankruptcy models (also known as financial distress prediction models) represent early-warning systems, which, according to the behavior of the indicators observed, suggest a possible future threat to financial health (Kovacova et al., 2019). Processing these models is important, especially for creditors who wish to know whether or not the company is able to satisfy its obligations. 
It can now be said that during the 19th century several errors were made in legislation in the United States regulating bankruptcy. The first US attempts at managing risk and credit reporting were established in special agencies, e.g. the Mercantile Agency and the Bradstreet Agency. The process of failure prediction started with the emergence of a large multi-unit corporation that was concerned with credit analysis, and which employed new professionals, so-called "credit men." The forecasting of failure developed in the early twentieth century following the establishment of the National Association of Credit Men (NACM) in the USA (Kurunmäki \& Miller, 2013), following which other systems of indicators were created in order to evaluate whether a given company faces bankruptcy or not (Soliman, 2008). Individual ratio indicators were instituted to evaluate a company's financial situation or its development by stipulating a single number which measured only one feature of a very complex economic process within the company. It was determined that if a pyramid system of indicators is construed suitably, the past, present and future performance of a company may be evaluated, with the first such system of indicators developed by Frank Donaldson Brown in 1912 for Du Pont de Nemours Company (Benjamin et al., 2018).

Later, much of this early work was focused on the study of the prediction of bankruptcy by statistical methods, with studies initially related to the prediction of corporate bankruptcy using univariate analysis. Early research includes the traditional studies of Fitzpatrick; Beaver; Smith \& Winakor; Merwin; Walter; Deakin; Edmister; Blum; Moyer, etc. (Bellovary et al., 2007). The first multivariate bankruptcy prediction model was developed by Altman in the late 1960s based on the Multiple Discriminant Analysis (MDA) analysis. An MDA model consists of a linear combination of variables, a method which provides the best distinction between failing and non-failing firms (Balcaen \& Ooghe, 2006). The original Altman's Z-Score model was based on the market value of the company and was therefore applicable only to publicly trading companies. This model was later revised with a complete reestimation to $Z^{\prime}$-score (Altman et al., 2017). The ZETA model was effective in classifying bankrupt companies up to five years prior to failure based on a sample of corporations consisting of manufacturers and retailers (Altman, 2013). The growing popularity of the Altman model has led to its use in various conditions with modifications for different sizes of companies or applications in other economies. Later the British economists of Taffler in 1977 presented a new Index by the application of the Z-Score to conditions in the United Kingdom (Agarwal \& Taffler, 2007). Another way of prediction features risk index models (for example, the Tamari model) based on simple point system on a special scale (Pakdaman, 2018).

In the early 1980s, conditional probability models such as logistic regression (logit) and probit regression analysis (Ohlson or Zmijewski model) studies appeared in the field of corporate bankruptcy prediction (Syamni et al., 2018). According to Aziz \& Dar (2006), these models express the probability of failure of a company as a dichotomous dependent variable that is the function of a vector of explanatory variables. There is a broad interest and literature basis for these methods. Another significant step forward came in the early 1990s with the development of statistical and analytical tools. A range of new techniques based on the analysis of larger data sets have been proposed in the literature (Prusak, 2018). Artificial intelligence methods have emerged based on new machine learning techniques which include neural networks (Tang et al., 2018), rough and fuzzy sets, bayesian models, genetic algorithms (Zelenkov et al., 2017), support vector machines, selforganizing maps, case-based reasoning, etc. 
A considerable amount of previous work in the subject area is given in case of the Czech Republic (Kovacova et al., 2019). Evidence from other studies as Kubenka (2016), Kovárník \& Hamplová (2017), Plihal et al. (2017) and others suggest that Altman and Taffler indexes, Kralicek Quick test, Credibility index, Zmijewski model and other foreign methods are widely used in the Czech Republic. Many studies have focused on adapting or adjusting these models to the conditions and environment of the national economy. In addition to modifying the existing models, new models have been created. The first application of prediction models to the Czech environment was made by Neumaierová \& Neumaier (2005), who determined four trustworthiness indices, i.e. IN95, IN99, IN01 and IN05. Balance analysis of Doucha evaluated companies on the basis of four main indicators which give total rating as their weighed average (Kubenka, 2016). Grunwald (2001) proposed index based on six ratio indicators and total points classification. Jakubik \& Teply (2011) presents index (JT index) based on seven financial indicators based on a linear regression of logit model. Dvoracek et al. (2012) created a bankruptcy model based on MDA method. Vavrina et al. (2013) focus on validation of DEA model for prediction of financial distress in agribusiness industry. Bems et al. (2015) introduce a scoring method based on the polygon shape classification algorithm. Hajek \& Olej (2015) connected financial indicators in bankruptcy prediction models with the language of company based on neural network, support vector machines and decision trees. Nemec \& Pavlik (2016) used standard logit model for predicting insolvency risk of the Czech companies. Karas \& Reznakova (2017) create a new bankruptcy prediction model based on classification and regression trees. The neural network model was proposed by Vochozka (2017), who combine both financial and non-financial indicators.

The disadvantages and shortcomings of prediction bankruptcy models are often mentioned in literature (Balcaen \& Ooghe, 2006; Grice \& Dugan, 2001; Vochozka, 2010). The main disadvantage of bankruptcy models is their empirical nature, which is based solely on research results and does not explain the causes of the financial difficulties of companies. Another problem is some stativity referring to the past accounting period. The problem of applicability of models to other countries or the relationship to economic conditions is often discussed in literature. Shortcomings can lie in the methodology (the question of simplicity, predictability, choice of indicators and their nature, method of evaluation, multicolinearity of indicators, data normality), sample characteristics (founding of company, industry, size) and data source (comparability, data availability, creative accounting).

\section{RESEARCH OBJECTIVE, METHODOLOGY AND DATA}

\subsection{Research objective}

The main purpose of the paper is to compare the accuracy of various methodologies of evaluation of financial health and bankruptcy forecasts and to decide which of the applied models has the highest prediction value. Another partial objective of the paper is to determine whether the accuracy rate of the bankruptcy models is changed with branches within which the companies operate or not. 


\subsection{Data}

The sample and data set consisted of the total of 90 Czech companies, out of which 45 were companies in bankruptcy and 45 were non-bankrupt companies. The database Albertina CZ Gold Edition was employed as the primary source of information of domestic companies. Information from balance sheets and profit and loss statements (in full format, periods 2010-2014) was used for prediction models calculations.

The companies in bankruptcy were selected on the basis of entries in the Insolvency Register. Insolvency proceedings were commenced against these companies in 2015, and bankruptcy was declared against these companies the same year or the subsequent year. The sample of nonbankrupt companies was created on the basis of two prestigious awards: Czech Stability Rating 2014 and Company of the Year 2015. Non-bankrupt companies were randomly selected from these two lists in terms of their size and turnover.

In terms of the legal form, limited liability companies [s.r.o.] prevail (83.3\%). Joint stock companies [a.s.] (13.3\%) and cooperatives (3.3\%) have a very marginal presence. The industrial branches (according to the CZ-NACE classification) C - Processing Industry (33.3\%), G - Wholesale and Retail (33.3\%) and F - Construction Industry (16.7\%) are most numerous within the set. Regarding other branches, the set includes companies operating in e.g. Agriculture, Forestry and Fishery (4.4\%). The other companies operate in Services (activities in the areas of real estate, administration and ancillary activities, etc.). With respect to headcount, companies with no more than 50 employees $(71 \%)$ prevailed. The most numerous group according to the turnover consisted of companies whose turnover did not exceed CZK $60 \mathrm{mil}$ (61.1\%).

\subsection{Methods}

There exist many models dealing with the bankruptcy prediction. After careful consideration, it was decided that univariate, MDA-based, logit and probit models best met the requirements for calculation and easier comparison of results with other studies. Chosen models are more flexible to calculate and are widely used for prediction of bankruptcy in the Czech Republic which is discussed in theoretical background. They were selected as the best models for the investigation until replication of the results of new models (based on artificial intelligence) is possible. Comparison and calculation of modern methods can be done to a limited extent only with the knowledge of the original methodology.

The evaluation of companies was performed by calculations according to the methodologies of models. Ratio indicators of given models were calculated for a five-year period according to the formulas (1-11). Classification of the company concerned as a company in bankruptcy or as a non-bankrupt company is based on results of ratio indicators and models according to the cut-off / threshold points. The methodology of the following models was used:

Altman $Z^{\prime}$-score (1983)

$Z^{\prime}=0.717 \cdot x_{1}+0.847 \cdot x_{2}+3.107 \cdot x_{3}+0.420 \cdot x_{4}+0.998 \cdot x_{5}$

where: $x_{1}=$ net working capital (current assets less current liabilities) / total assets; $x_{2}=$ retained earnings / total assets; $x_{3}=$ earnings before interests and taxes $(\mathrm{EBIT}) /$ total assets; $x_{4}=$ market value equity / book value of total debt; $x_{5}=$ sales / total assets. 
Altman Z* score (1995)

$Z^{*}=6.56 \cdot x_{1}+3.26 \cdot x_{2}+6.72 \cdot x_{3}+1.055 \cdot x_{4}$

where: variables are the same as $Z^{\prime}$-score and variable $x_{5}$ is excluded.

Trustworthiness Index IN99 (2002)

IN99 $=-0.017 \cdot x_{1}+4.573 \cdot x_{2}+0.481 \cdot x_{3}+0.015 \cdot x_{4}$

where: $x_{1}=$ assets / liabilities; $x_{2}=$ EBIT / assets; $x_{3}=$ revenue / assets; $x_{4}=$ assets / (short-term liabilities and short-term bank loans).

Trustworthiness Index IN05 (2002)

IN05 $=0.13 \cdot x_{1}+0.04 \cdot x_{2}+3.97 \cdot x_{3}+0.21 \cdot x_{4}+0.015 \cdot x_{5}$

where: $x_{1}=$ assets $/$ liabilities; $x_{2}=$ EBIT $=$ interests; $x_{3}=$ EBIT $/$ assets; $x_{4}=$ revenue $/$ assets; $x_{5}=$ current assets / short-term liabilities and maximum value of variable $x_{2}$ is 9 .

Quicktest (1993)

Overall position $=\left(q_{1}+q_{4}\right) / 2+\left(q_{2}+q_{3}\right) / 2$

where: The evaluation scale uses the point evaluation $\left(q_{1}-q_{4}\right)$ from 1 up to 5 for each financial ratio $\left(x_{1}-x_{4}\right)$. The final grade (overall position) is the arithmetic average of evaluated ratios of financial stability and revenue position (i.e. $q_{1}, q_{2}, q_{3}$ and $q_{4}$ ). Financial ratios are: $x_{1}=$ equity / total assets; $x_{2}=$ operating cash flow $/$ revenues; $x_{3}=$ EBIT $/$ total assets; $x_{4}=$ (liabilities + loans - cash) / operating cash flow. Note that according to Kralicek, CF is calculated as Profit(loss) current year $+(-)$ changes in reserve funds $+(-)$ changes in reserves and according to Kislingerová as - it is calculated EBITDA + depreciation + changes in reserve funds.

Z-Score (1984)

$Z=-4.336-4.513 \cdot x_{1}+5.679 \cdot x_{2}-0.004 \cdot x_{3}$

Probability of the bankruptcy $=f(Z)$

where: $x_{1}=$ EAT $/$ total assets; $x_{2}=$ liabilities / assets; $x_{3}=$ current assets / short-term liabilities. The probability of bankruptcy is determined by using the result of equation $Z$ in the function of the normal distribution.

Taffler Model (1984)

$T=0.53 \cdot x_{1}+0.13 \cdot x_{2}+0.18 \cdot x_{3}+0.16 \cdot x_{4}$

where: $x_{1}=$ earnings before taxes $(\mathrm{EBT}) /$ short-term liabilities; $x_{2}=$ current assets $/$ total liabilities; $x_{3}=$ short-term liabilities / total assets; $x_{4}=$ (financial assets - short-term liabilities) / (operating costs - depreciation)

Credibility Index (1993)

$I B=1.5 \cdot x_{1}+0.08 \cdot x_{2}+10 \cdot x_{3}+5 \cdot x_{4}+0.3 \cdot x_{5}+0.1 \cdot x_{6}$

where: $x_{1}=$ Cash Flow $/$ Total liabilities and Equity; $x_{2}=$ Total Capital / Total liabilities and Equity; $x_{3}=$ EBIT $/$ Total Capital $x_{4}=$ EBT $/$ Revenues; $x_{5}=$ Inventory / Total Assets; $x_{6}=$ Equity / Total Capital. 
Index of Bonity (2001)

$G I B=1 / 6 \cdot\left(x_{1} /(\right.$ interest rate $)+x_{2} /($ interest rate $\cdot(1-$ tax rate $\left.))+x_{3} / 1.2+x_{4} / 0.7+x_{5} / 0.3+x_{6} / 2.5\right)$

where: $x_{1}(\mathrm{ROA})=\mathrm{EBTI} /$ total assets; $x_{2}(\mathrm{ROE})=\mathrm{EAT} /$ equity; $x_{3}($ Operating quick ratio $)=$ (short-term receivables + short-term financial assets) / short-term liabilities; $x_{4}$ (Inventory to working capital $)=($ current assets - short-term liabilities - short-term bank credits $) /$ inventories; $x_{5}($ Net credits $)=($ EAT + depreciation $) /\left(\right.$ liabilities - reserves - short-term financial assets; $x_{6}$ (Times interest Earned Ratio) $=$ EBIT $/$ interests.

Balance Analysis I. (1996)

$B A I=(2 \cdot S+4 \cdot L+1 \cdot A+5 \cdot R) / 12$

where: Index of stability $(S)=$ equity / total assets; Index of liquidity $(L)=$ (short-term financial property + receivables $) / 2.17 \cdot$ current liabilities; Index of activity $(A)=$ gross revenue $/$ total liabilities; Index of rentability $(R)=8 \cdot$ EAT / equity

\section{Classification Model}

The reliability of the accurate classification of units may be verified by a confusion matrix, showing numbers of accurately categorized units along the diagonal, and numbers of erroneously categorized units outside the diagonal (Fawcett, 2006). The confusion matrix reflects, in a wellorganized manner, the division into classes, proceeding from two possible conditions, which are indicated as positive or negative. Its boxes will be formed by combination of the categorization of objects into classes based on reality and their classification. The grey zone extends the confusion matrix into form $2 \times 3$ and it is not included in the class of accurate and erroneous classifications. The success rate of the models is measured over a five-year period, on the basis of determination of accurate classification (i.e. prosperous / non-bankrupt companies are classified with a good "financial health", companies in bankruptcy as companies in "financial distress"), and errors in types I and II in the confusion matrix. The total success rate equals the difference of accuracy (ACC) and error rate (ERR) of the model.

$$
\begin{aligned}
& E R R=" F P+F N " / " T P+T N+F P+F N " \\
& A C C=" T P+T N ” / " T P+T N+F P+F N "
\end{aligned}
$$

where: $\quad \mathrm{TN}-$ truly negative observations classified as negative

FP - truly negative observations classified as positive (error I)

FN - truly positive observations classified as negative (error II)

$\mathrm{TP}$ - truly positive observations classified as positive

Total success rate of classification $=A C C-E R R$

\section{Statistical evaluation}

The obtained results were then subjected to statistical analysis by "individual tests of equal and given proportions without correlation to continuity". In particular, statistical hypotheses were formulated for each category of company branches: 
- $\left(\mathrm{H}_{0}\right)$ The null hypothesis: there is no difference in total success rate of models classification among companies from various branches.

- $\left(\mathrm{H}_{\mathrm{A}}\right)$ The statistical alternative hypothesis: there is a difference in the total success rate of models classification among companies from various branches in at least one case.

The results are interpreted at alpha significance level $=0.05$ using $\mathrm{p}$-value. The Holm's method of adjusting the level of significance reached was used in the case of multiple comparisons of relative frequencies. The evaluation of statistical tests is performed using R 3.5.3.

\section{RESULTS AND DISCUSSION}

The results are structured as follows: development and introduction to bankruptcy in The Czech Republic in the last 10 years including global financial crisis, results of models evaluation and comparing models results for various branches.

\subsection{The development of bankruptcy in the Czech Republic in the last 10 years}

In the last decade, the number of insolvency proceedings and the annual number of bankruptcies have considerably changed in the Czech Republic. The number of insolvency proceedings in the year 2008 was 5,354 and the number peaks in the year 2013 (36,909 insolvency proceedings). Since this year, the number of insolvency proposals was gradually declining to 20,695 in 2018 (Crefoport, 2019). A similar trend is reported by the number of bankruptcies declared in the Czech Republic, which reached its historical maximum in 2014 (2,403 bankruptcy companies).

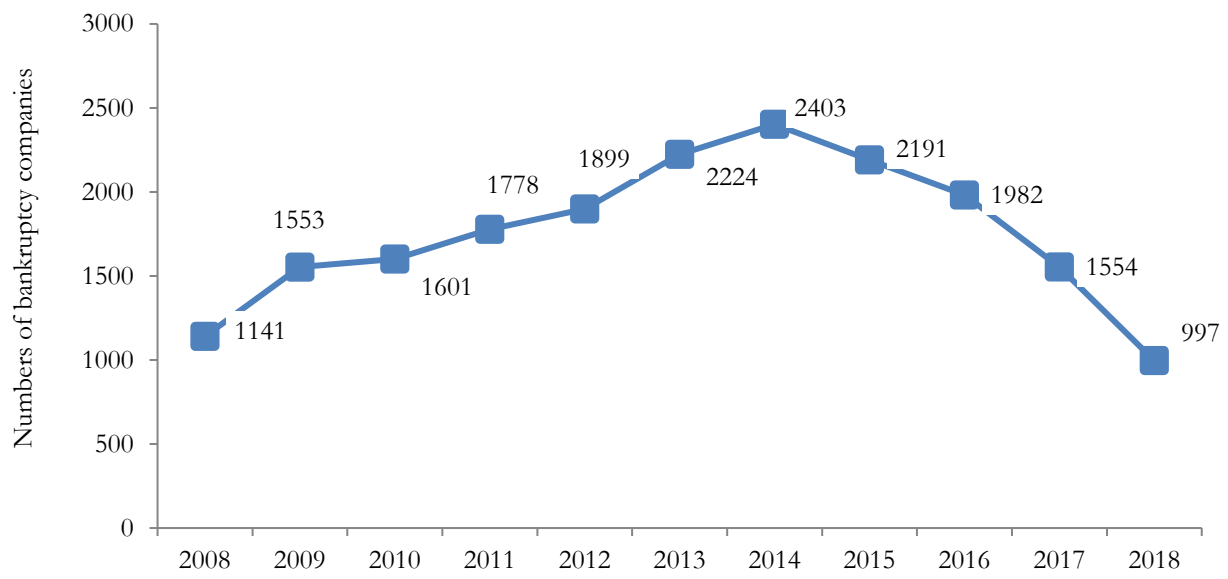

Fig. 1 - Numbers of bankruptcy companies in the Czech Republic in the years 2008-2018. Source: Crefoport (2019)

Our study is focused on the period when, the number of bankruptcy declaration showed an increasing trend. Although it may seem outdated, it is important to evaluate this data. The current economic growth cannot last forever, companies must now prepare for the next crisis. Findings from a similar period in history will be important for the future. The development of bankrupt- 
cies in the Czech Republic is depicted in Figure 1. Of course, this development is closely related to the impact of the global financial economic crisis, which, among other things, also influenced the competitiveness of Czech companies to a large extent.

The most insolvency proceedings for legal entities end with a declaration of bankruptcy (unless the proceeding is rejected due to lack of company assets or rejected for formal reasons), i.e. most often by bankruptcy or reorganization. Bankruptcy declaration brings the relative satisfaction of the creditors' claims. Schönfeld et al. (2013) state that between 2008 and 2012, the average level of creditors' satisfaction was found to be only $3.62 \%$. It is because bankruptcy and bad financial health represent not only a financial threat for the company itself, but also for its business partners. Therefore, it is necessary to monitor it and predict it regularly. Then, a regular company assessment of using bankruptcy or creditworthy models can be a significant competitive advantage.

\subsection{Results of models evaluation}

The calculation by means of the confusion matrix was carried out for each model. The success rate of the evaluation of classification of the models was determined based on the results of confusion matrices, specifically the total average error rate and classification accuracy in percentage terms. The results show that the lowest error rate was achieved by Kralicek Quicktest $(1.56 \%)$. On the contrary, the highest error rate was reached by Taffler model (36.67\%) and its modified version $(34.89 \%)$. Comparison of the error rate of classification of the individual models is illustrated in Figure 2 below.

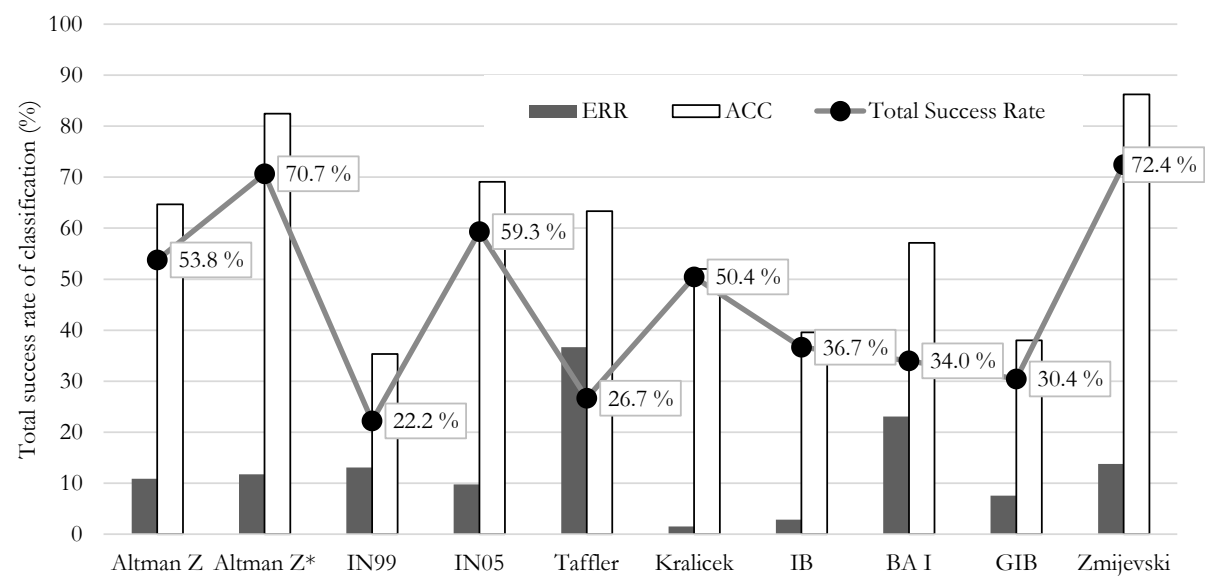

Fig. 2 - Evaluation according to the error rate (ERR), accuracy (ACC) and total success rate of classification.

Source: own research

When the individual models are evaluated based on the accuracy of classification (Figure 2), the highest total average accuracy is achieved by Zmijewski model (86.22\%). Altman model Z* is another model exceeding $80 \%$ of accuracy (average value $82.44 \%$ ). Other models have reached low- 
er values of the total accuracy of classification. On the contrary, the lowest rate of classification accuracy was identified for index IN99 (approximately 35.33\%) and Credibility index (39.56\%).

With respect to the fact that the evaluation of accuracy and error rate of classifications yields different results (the best and worst evaluated models differ), it will be suitable to determine the total success rate of models on the basis of combination of both methodologies.

Differences were caused by one of the methodical problems, specifically the "grey zone" (intermediate classification stages are not indicated as the grey zone in the Credibility index and Grünwald index of bonity, but still perform a similar function). The classification of the portion of companies in intermediate classification stages (and the grey zone) prevails in Grünwald index of bonity, IN99 and Credibility Index (IB). On the contrary, the grey zone is not considered by Taffler model and Zmijewski model.

In order to exclude the effect of intermediate stages and the grey zone in the classification, the summary indicator of success rate was obtained by deducting the total error from the accuracy of classification of the individual models. Accordingly, the result signifies both the accuracy and error rate of the classification. A higher value corresponds to a better total success rate of the given model. This procedure allows for comparison of the individual models irrespective whether the grey zone has been defined or not.

The highest total success rate of classification (Figure 3) was achieved by Zmijevski model (72.44\%) thanks to the high level of accuracy and low error rate. A very good position was also achieved by Altman Index Z* (70.67\%). Regarding the Czech models, index IN05 (59.33\%) can be recommended. On the other hand, the worst position was reached by index IN99 $(22.22 \%)$, chiefly due to the low accuracy of classification. The Taffler model has proved to have poor classification ability (26.67\%). Their weak points include the high error rate in particular.

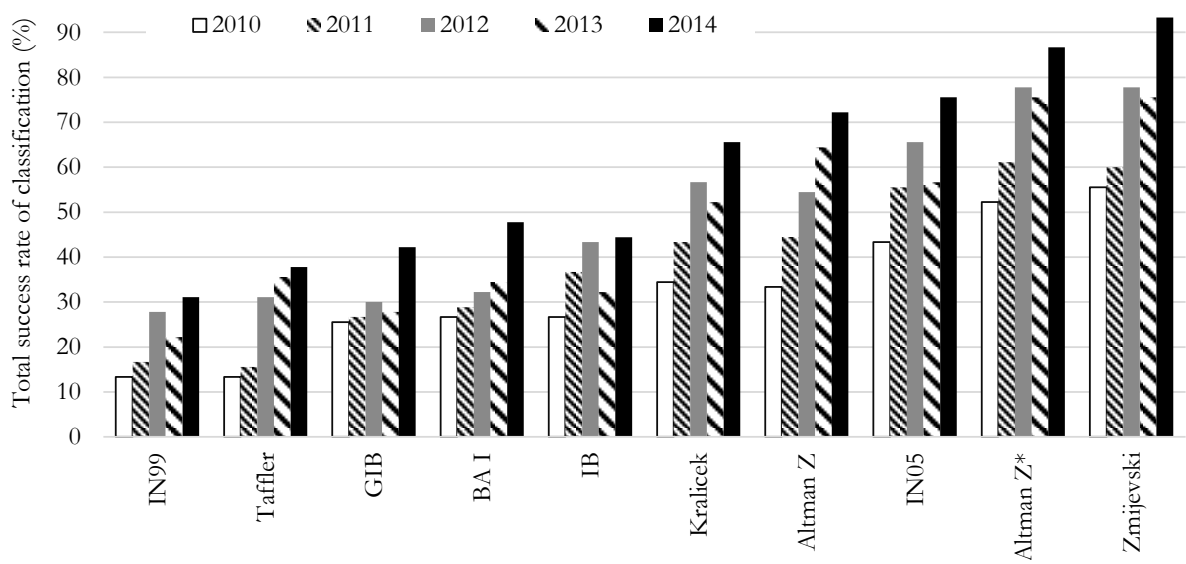

Fig. 3 - Evaluation according to the total success rate in the years 2010-2014 (\%). Source: own research

In addition to the confusion matrix, ROC curves are used to evaluate the accuracy of the models. This method is used quite often, for example in the study of Karas \& Reznakova (2018). Unfortu- 
nately, this method is not very suitable for comparing 10 models, as was performed in our study. Due to plotting a larger number of ROC curves in a single graph, a process which can be quite complicated, only the confusion matrix is used in this study.

\subsection{The comparison of models results for various branches}

As for the impact on classification, differences in the total success rate of the models were evaluated for various branches (construction industry, wholesale and retail, processing industry), with differences in the success rate of classification of the models across the individual branches summarized in Figure 4. Overall, the Altman models $Z^{\prime}$ and $Z^{*}$ and also Zmijewski prevailed in terms of good results. The models that achieve the worst evaluation across the branches are the Taffler model and the index IN99.

The construction industry (15 companies in total) saw an improvement in the average success rate especially with index IN99 and Grünwald index of bonity. Index IN99 even reached a higher evaluation level in the construction industry as compared with the other branches (relatively good results are also obtained by this index in wholesale and retail). Contrariwise, the total success rate of Balance Analysis I deteriorated, mainly due to an increase in the error rate. A zero error rate was recorded for Kralicek Quicktest.

Retail and wholesale (30 companies in total) was characterized by a decrease in the success rate for the otherwise dominant models, i.e. Altman Z and $Z^{*}$, and also the Zmijewski model. In comparison with other branches, the Taffler model plunged to its lowest value level (the worst result of all for this model). With the exception of index IN99 and Balance Analysis I, the average error rate increased for all the other models.

In the processing industry (30 companies), the success rate of classification rose for all models except the index IN99. The average error rate dropped for every model. The maximal success rate was reached by the index IN05 and the Taffler model. This result was likely caused by the inclusion of manufacturing companies, which the Taffler model identified as successful. Interestingly, the success rate of the Altman model Z* overtook that of the Zmijewski model, the model that showed the best results in other cases.

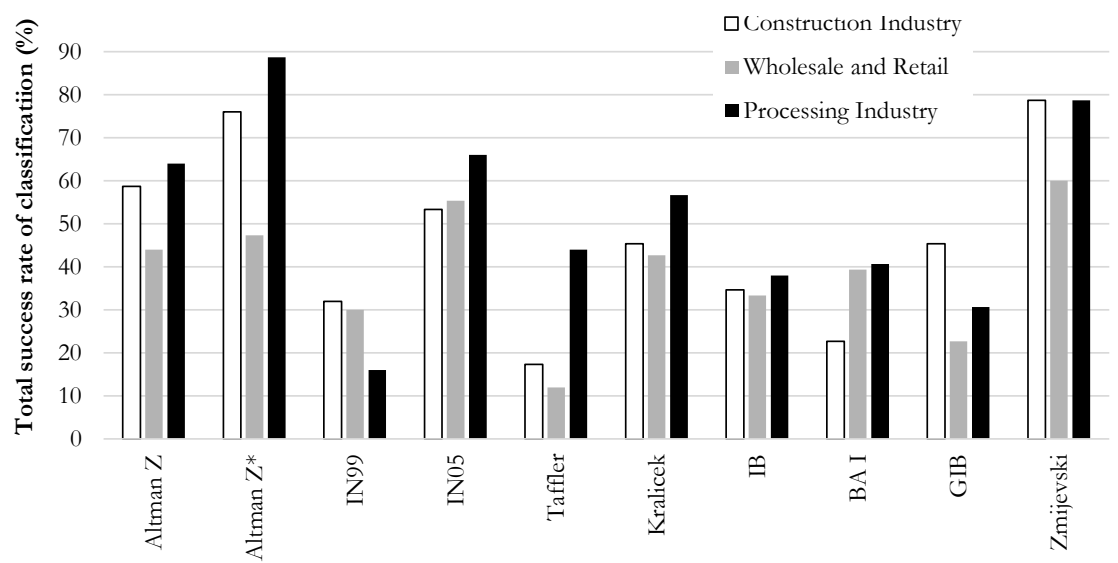

Fig. 4 - Evaluation of models in different branches based on the total success rate (\%). Source: own research 
In the other branches (15 companies), predominantly operating in the area of services, the success rate of the index IN99 and Balance Analysis I dropped to the minimum level. For both models, the main reason for this was the error rate of classification. In comparison with the results in the other branches, the maximum values of success were reached by the Kralicek Quicktest and the Credibility Index.

\subsection{Evaluation of hypothesis $\mathrm{H}_{0}$}

At the 5\% level of significance, we reject the null hypothesis $\mathrm{H} 0$ for all the analyzed models except IN05 (p-value $=0.0877)$. The Credibility index $(\mathrm{p}$-value $=0.6908)$. Altman Z*, IN99, Taffler and Zmijevski models show the major differences between the branches. A deeper analysis shows that the most statistically significant differences can be found between Wholesale and Retail and the Processing Industry, especially for both Altman models Z and Z*, IN99, the Taffler model and Zmijewski. The biggest difference between branches (the Construction Industry and Wholesale and Retail) was found in Altman Z*, GIB and the Zmijewski model. Statistically significant differences between the Construction Industry and the Processing Industry were shown in only two models (IN99 and Taffler).

The results show that the type of branch analyzed affects the success rate of credibility and bankruptcy models to a considerable extent, a finding confirmed by the results of earlier research. Kopta (2009) shows that in the agricultural sector the success of the classification of the different models varies as well. This supports our conclusion that the industry in which the company operates influences the success of model classification. A comparison of results of different credibility models in the textile industry were presented by Kovárník \& Hamplová (2017), with the findings showing that differences between given models exist. The most critical model is the Grünwald Index of Bonity (Grünwald, 2001), a model which showed the highest number of companies in the distress zone. Unfortunately, this study does not indicate the true state of the company, and therefore it is not possible to determine which model was the most accurate. A study of the success rate in a prediction in the construction industry was proposed by Lunacek (2015), who found in construction industry with the Zmijewski model a success rate of $95 \%$. These results are remarkably close to our findings. An assessment regarding the prediction of success rate of ths core of the Altman $Z^{*}$ model by Kubenka \& Kralova (2013) provides similarly good results. These studies confirmed the good performance of Zmijewski model and Altman $\mathrm{Z}^{*}$ in the construction industry.

Almost every method used for statistical or other corporate failure prediction has some limitations or problems in specific conditions. Among other measurments, these limitations obviously also affect the level of accuracy of model results in subsequent comparisons. These limitations and problems are more precisely identified in a research project describing 35 years of studies on business failure (Balcaen \& Ooghe, 2006). It is recommended that each company use multiple models to evaluate its financial health, as different problems may be revealed by different models. 


\section{CONCLUSION}

During the global economic crisis, the number of insolvency proceedings and the number of bankruptcies in the Czech Republic significantly changed. Our article focuses on the period when the number of announced bankruptcies was increasing. The main aim of the paper was to compare the accuracy of various prediction models used for evaluating financial health and bankruptcy prediction. Our main findings seem to suggest that the success rate of bankruptcy prediction models vary considerably depending on which industry is evaluated. These clear results are presented as one of the main achievements of this work.

This research seeks to make a substantial contribution to the analysis and evaluation of widely used bankruptcy models in the Czech Republic, with our study revealing the models with better predictive ability. These results likewise confirm the conclusions of a number of previous researches. The highest total success rate of classification was achieved by the Zmijevski model as shown by the high level of accuracy and low error rate. When the individual models are compared based on the accuracy of classification, the highest total average accuracy was achieved by the Zmijewski model. The results show that the lowest error rate was achieved by Kralicek Quicktest. Both of the Zmijevski model and the Kralicek Quicktest had the highest predictive value during the global financial crisis. The results of our research can be incorporated into a practical application strategy to identify which companies are or are not in financial distress. This evaluative capacity will make it easier for managers to choose methodologies for evaluating the financial situation of their companies. Knowing the real situation of companies in terms of poor condition can reduce investors' financial losses. This result might be considered in terms of potential areas for future direction.

The partial aim of the paper was to find out whether or not the accuracy classification is influenced by branches. The hypothesis about differences between branches was confirmed. The results of this work will unravel and shed light on the process of determining prediction success rate in relation to different industry branches. Differences in the overall classification exists among companies in different branches for all the given models except IN05 and the Credibility Index, with the most statistically significant differences shown between the Wholesale and Retail and the Processing Industry. These results demonstrate that these criteria represent an effective way of distinguishing among models in choosing a method for predicting the financial distress of companies. The analysis of the results may also lead to a better understanding of the factors influencing the formation of new models as well as their potential shortcomings. This can reduce the time and economic requirements of their creation.

Prediction models represent early warning systems, as the selected multiple indicators signal potential threats to financial health. These models allow users to compare the future competitiveness of accounting units, and are thus suitable for future as well as present decision-making. Our findings from the period of the financial crisis will be important for the future and can help decide which models can be used for new predictions for particular industry branches. Still the theoretical background along with recent studies suggest that new methods based on the artificial intelligence have been emerging in the field of bankruptcy prediction. These methods seem to have high prediction success rate and they seem to eliminate some of the limitations of basic statistical models. This is a promising potential area for further research. 


\section{Acknowledgements}

The authors seek to acknowledge their gratitude for the financial support to carry out this research provided by IGS No.: IGS05C1.

\section{References}

1. Aziz, A. M., \& Dar, H. A. (2006). Predicting corporate bankruptcy: where we stand? Corporate Governance: The international journal of business in society, 6 (1), 18-33. https://doi. org/10.1108/14720700610649436

2. Agarwal, V., \& Taffler, R. J. (2007). Twenty-five years of the Taffler z-score model: Does it really have predictive ability? Accounting and Business Research, 37 (4), 285-300. https://doi.org /10.1080/00014788.2007.9663313

3. Altman, E. I. (2013). Predicting Financial Distress of Companies: Revisiting the Z Score and ZETA Models. In A. R. Bell, Ch. Brooks, \& M. Prokopczuk (Ed.). Handbook of Research Methods and Applications in Empirical Finance. Northampton: Edward Elgar Publishing. https://doi.org/10.4337/9780857936080.00027

4. Altman, E. I., Iwanicz-Drozdowska, M., Laitinen, E. K., \& Suvas, A. (2017). Financial Distress Prediction in an International Context: A Review and Empirical Analysis of Altman's Z-Score Model. Journal of International Financial Management \& Accounting, 28 (2), 131-171. https://doi.org/10.1111/jifm.12053

5. Balcaen, S., \& Ooghe, H. (2006). 35 years of studies on business failure: an overview of the classic statistical methodologies and their related problems. The British Accounting Review, 38 (1), 63-93. https://doi.org/10.1016/j.bar.2005.09.001

6. Bellovary, J. L., Giacomino, D. E., \& Akers, M. D. (2007). A Review of Bankruptcy Prediction Studies: 1930 to Present. Journal of Financial Education, 33 (1), 1-42.

7. Bems, J., Stary, O., Macas, M., Zegklitz, J., \& Posik, P. (2015). Innovative default prediction approach. Expert Systems with Applications, 42 (17-18), 6277-6285. https://doi.org/10.1016/j. eswa.2015.04.053

8. Benjamin, S. J., Bin Mohamed, Z., \& Marathamuthu, M. S. (2018). DuPont analysis and dividend policy: empirical evidence from Malaysia. Pacific Accounting Review, 30 (1), 52-72. https://10.1108/par-05-2015-0019

9. Crefoport (2019). Vývoj insolvencí v České republice v roce 2018. Praha: Crefoport. Retrieved April 16, 2019. http://crefoport.cz/wp-content/uploads/2019/01/TZ_ Insolvence_2018_fin.pdf

10. Dvoracek, J., Sousedikova, R., Repka, M., Domaracka, L., Bartak, P., \& Bartosikova, M. (2012). Choosing a method for predicting economic performance of companies. Metalurgija, $51(4), 525-528$.

11. Fawcett, T. (2006). An introduction to ROC analysis. Pattern Recognition Letters, 27 (8), 861-874. https://doi.org/10.1016/j.patrec.2005.10.010

12. Grice, J. S., \& Dugan, M. T. (2001). The Limitations of Bankruptcy Prediction Models: Some Cautions for the Researcher. Review of Quantitative Finance and Accounting, 17 (2), 151-166. https://doi.org/10.1023/a:1017973604789 
13. Grünwald, R. (2001). Analyza finančni divereryhodnosti podniku: Testujeme finančni dìvèryhodnost svébo obchodního partnera či klienta podle jeho účetních výkazư. Praha: Ekopress.

14. Hajek, P., \& Olej, V. (2015). Word Categorization of Corporate Annual Reports for Bankruptcy Prediction by Machine Learning Methods. In P. Kral \& V. Matousek (Eds.), Text, Speech, and Dialogue. Berlin: Springer-Verlag Berlin.

15. Jakubik, P., \& Teply, P. (2011). The JT index as an indicator of financial stability of coporate sector. Prague Economic Papers, 20 (2), 157-176. https://doi.org/10.18267/j.pep.394

16. Karas, M., \& Reznakova, M. (2017). Predicting the Bankruptcy of Construction Companies: A CART-Based Model. Inzinerine Ekonomika-Engineering Economics, 28 (2), 145-154. https://doi.org/10.5755/j01.ee.28.2.16353

17. Karas, M., \& Reznakova, M. (2018). Building a Bankruptcy Prediction Model: Could Information about Past Development Increase Model Accuracy? Polish Journal of Management Studies, 17 (1), 116-130. https://doi.org/10.17512/pjms.2018.17.1.10

18. Kopta, D. (2009). Possibilities of financial health indicators used for prediction of future development of agricultural enterprises. Agricultural Economics-Zemedelska Ekonomika, 55 (3), 111-125. https://doi.org/10.17221/589-AGRICECON

19. Kovacova, M., Kliestik, T., Valaskova, K., Durana, P., \& Juhaszova, Z. (2019). Systematic review of variables applied in bankruptcy prediction. Oeconomia Copernicana, 10 (4), 743-772. https://doi.org/10.24136/oc.2019.034

20. Kovárník, J., \& Hamplová, E. (2017). The Comparison of Prediction Ability of Selected Credibility Models in the Textile Industry in the Czech Republic. Paper presented at the The 11th International Days of Statistics and Economics, Praha, 761-770. Slaný: Melandrium.

21. Kubenka, M. (2016). The Success of Business Failure Prediction Using Financial Creditworthy Models. Brno: Masaryk University.

22. Kubenka, M., \& Kralova, V. (2013). Z " score in assessing the financial health in the construction sector. E \& M Ekonomie a Management, 16 (1), 101-112.

23. Kurunmäki, L., \& Miller, P. (2013). Calculating failure: The making of a calculative infrastructure for forgiving and forecasting failure. Business History, 55 (7), 1100-1118. https://doi.org/10.1080/00076791.2013.838036

24. Lunacek, J. (2015). Selection of Bankruptcy Prediction Model for the Construction Industry - A Case Study from the Czech Republic. Norristown: Int Business Information Management Assoc-Ibima.

25. Nemec, D., \& Pavlik, M. (2016). Predicting insolvency risk of the Czech companies. Bratislava: Letra Interactive.

26. Neumaierová, I., \& Neumaier, I. (2002). Výkonnost a tržni hodnota firmy. Praha: Grada Publishing.

27. Neumaierová, I., \& Neumaier, I. (2005). Index IN05. In P. Červinek (Ed.). Sborník příspěvků z mezinárodní vědecké konference Evropské finanční systémy. Paper presented at Evropské finanční systémy. Brno: Masaryk University. 
28. Pakdaman, H. (2018). Investigating the ability of Altman and Springate and Zmijewski and grover bankruptcy prediction models in Tehran Stock Exchange. Espacios, 39 (14). https:// doi.org/10.5901/mjss.2016.v7n4S1p208

29. Plihal, T., Sponerova, M., \& Sponer, M. (2017). Comparison of Bankruptcy Prediction Models in Relation to SME Segment in the Czech Republic. Brno: Mendel University.

30. Prusak, B. (2018). Review of Research into Enterprise Bankruptcy Prediction in Selected Central and Eastern European Countries. International Journal of Financial Studies, 6 (3). https://doi.org/10.3390/ijfs6030060

31. Remenaric, B., Kenfelja, I., \& Mijoč, I. (2018). Creative Accounting - Motives, Techniques and Possibilities of Prevention. Ekonomski Vjesnik. / Econviews, 31 (1), 193-199.

32. Schönfeld, J., Smrčka, L., \& Malý, T. (2013). Insolveční řízení v České republice: skutečný výnos věritelů je velmi nízký. In Sborník z mezinárodní vědecké konference Insolvence 2013 - konec jedné etapy, začátek další? Praha: Oeconomica.

33. Shi, Y., \& Li, X. N. (2019). An overview of bankruptcy prediction models for corporate firms: A systematic literature review. Intangible Capital, 15 (2), 114-127. https://doi. org/10.3926/ic.1354

34. Soliman, M. T. (2008). The use of DuPont analysis by market participants. Accounting Review, 83 (3), 823-853. https://doi.org/10.2308/accr.2008.83.3.823

35. Syamni, G., Abd Majid, M. S., \& Siregar, W. V. (2018). Bankruptcy Prediction Models and Stock Prices of the Coal Mining Industry in Indonesia. Etikonomi, 17 (1), 57-68. https://doi. org/10.15408/etk.v17i1.6559

36. Tang, Y. J., Ji, J. K., Gao, S. C., Dai, H. W., Yu, Y., \& Todo, Y. (2018). A Pruning Neural Network Model in Credit Classification Analysis. Computational Intelligence and Neuroscience. https://doi.org/10.1155/2018/9390410

37. Vavřina, J., Hampel, D., \& Janová, J. (2013). New approaches for the financial distress classification in agribusiness. Acta Universitatis Agriculturae et Silviculturae Mendelianae Brunensis, 61 (4), 1177-1182. https://doi.org/10.11118/actaun201361041177

38. Vochozka, M. (2010). Development of methods for comprehensive evaluation of business performance. Politicka Ekonomie, 58 (5), 675-688. https://doi.org/10.18267/j.polek.754

39. Vochozka, M. (2017). Formation of complex company evaluation method through neural networks based on the example of construction companies' collection. Ad Alta-Journal of Interdisciplinary Research, 7 (2), 232-239.

40. Zelenkov, Y., Fedorova, E., \& Chekrizov, D. (2017). Two-step classification method based on genetic algorithm for bankruptcy forecasting. Expert Systems with Applications, 88 (1), 393-401. https://doi.org/10.1016/j.eswa.2017.07.025 


\section{Contact information}

Ing. Martin Pech, Ph.D.

University of South Bohemia in Ceské Budèjovice

Faculty of Economics

Department of Management

Czech Republic

E-mail:mpechac@ef.jcu.cz.

ORCID:0000-0002-0807-3613

Ing. Jaroslava Prazakova, Ph.D.

University of South Bohemia in Ceské Budéjovice

Faculty of Economics

Department of Accounting and Finances

Crech Republic

E-mail:smoloj@ef.jcu.cz.

ORCID: 0000-0003-3676-0602

\section{Ing. Lucie Pechova}

University of South Bohemia in Ceské Budéjovice

Faculty of Economics

Crech Republic

E-mail:LuckaOndokova@seznam.cz. 